\title{
Pembangunan Sistem Pakar Untuk Diagnosis Penyakit Tulang dan Sendi
}

\author{
Hafiz Budi Firmansyah¹, Aswedi Putra² \\ ${ }^{1}$ Program Studi Teknik Informatika, Institut Teknologi Sumatera, Lampung, Indonesia \\ ${ }^{2}$ Fakultas Kedokteran, Universitas Malahayati, Lampung, Indonesia
}

\begin{abstract}
:
Abstract-In Indonesia the numbers of orthopaedic surgeons are still not able to cover all demand. Badan Pusat Statistik (2015) reported that there are merely two orthopaedic surgeons in Lampung province having to serve about 8.117 .268 people. Meanwhile, based on Ministry of Health of Republic of Indonesia, the ideal ratio between doctor and people is 12.2 doctor for each 100.000 people. Besides that, sometimes the surgeons need to serve more than one medical facility. Consequently, the patients might feel unpleasant. The lack of human resources becomes the main reason for developing expert system for diagnosing orthopaedic diseases. The expert system is able to diagnose orthopaedic diseases as well as fracture, dislocation, osteoarthritis and osteoporosis. The system is developed by using forward chaining methodology. This methodology is suitable for identifying a disease based on their symptoms. The result shows that the expert can answer $45 \%$ of questions by identifying 6 main symptoms without continuing to following symptom questions.
\end{abstract}

\section{Keywords: Expert System, Orthopaedic Diseases, Forward Chaining}

\section{Pendahuluan}

Dewasa ini, Indonesia masih kekurangan jumlah dokter spesialis tulang dan sendi [9]. Menurut Kementerian Kesehatan, saat ini hanya ada 500 dokter spesialis bedah tulang dan sendi yang melayani 250 juta penduduk di Indonesia. Salah satu provinsi yang masih kekurangan dokter spesialis bedah tulang dan sendi adalah Provinsi Lampung. Menurut sensus penduduk yang dilakukan Badan Pusat Statistik, jumlah penduduk Provinsi Lampung mencapai 8.117.268 jiwa. Dengan jumlah penduduk sebanyak delapan juta jiwa, Provinsi Lampung hanya memiliki lima belas orang dokter spesialis tulang dan sendi. Sehingga jika dirata-rata, satu dokter spesialis bedah tulang dan sendi harus melayani 540.000 orang penduduk. Padahal, menurut Kementerian Kesehatan, rasio ideal dokter spesialis dan jumlah penduduk adalah 12,2 orang per 100.000 penduduk [5]. Sehingga, idealnya satu orang dokter spesialis hanya bertugas untuk melayani sekitar 8.000 pasien.

Minimnya jumlah dokter spesialis berdampak pada kualitas layanan yang diberikan. Dampak yang paling signifikan dirasakan oleh pasien adalah waktu tunggu dokter [4]. Untuk mendapatkan pelayanan medis, seorang pasien seringkali harus menunggu dokter terlebih dahulu karena dokter harus memeriksa pasien di fasilitas kesehatan lain atau memeriksa pasien yang sudah mengantri terlebih dahulu. Hal ini disebabkan karena belum idealnya rasio jumlah dokter spesialis bedah tulang dan sendi dan minimnya fasilitas kesehatan penunjang di luar kota Bandar Lampung [4].

Permasalahan tersebut dapat diatasi dengan melakukan transfer dan transformasi kepakaran seorang pakar ke dalam sebuah program yaitu, sistem pakar [6][8]. Tujuan pengembangan sistem pakar adalah tidak untuk menggantikan peran seorang pakar melainkan lebih cenderung kepada transfer pengetahuan dari seorang pakar ke dalam bentuk perangkat lunak [7]. Sehingga, aplikasi sistem pakar yang dikembangkan hanya akan berperan seolah-olah sebagai dokter yang akan menjawab kemungkinan penyakit yang diderita pasien di mana kehadiran dokter untuk melakukan pemeriksaan fisik dan penunjang tetap harus dilakukan. Aplikasi sistem pakar dapat mengurangi durasi pemeriksaan karena sebagian besar waktu pemeriksaan dihabiskan dengan mekanisme tanya jawab antara pasien dan dokter atau umum disebut dengan anamnesa. Dengan pengembangan aplikasi sistem pakar, dokter dapat lebih fokus pada pemeriksaan fisik, pemeriksaan penunjang dan tindakan medis lainnya.

Dalam penelitian ini dikembangkan sebuah sistem pakar yang terintegrasi dengan aplikasi penyimpanan data rekam medis. Sistem pakar dikembangkan dengan arsitektur berbasis web. Sistem pakar dikembangkan dengan menggunakan metode forward chaining. Metode forward chaining sesuai untuk diimplementasikan dalam sebuah sistem pakar yang memiliki kemampuan untuk mendiagnosis suatu penyakit [1]. 
Artikel ini terdiri dari lima bagian yaitu pendahuluan, metodologi penelitian, hasil analisis dan pembahasan, kesimpulan dan daftar pustaka. Bagian pertama membahas permasalahan dan latar belakang masalah. Dalam bagian ini dijabarkan juga landasan teori dan tinjauan pustaka yang dilakukan dalam melakukan penelitian. Bagian kedua menguraikan metodologi knowledge engineering yang berfokus kepada pengembangan sistem pakar. Bagian analisis dan pembahasan menjelaskan hasil knowledge engineering yang dilakukan.

Pada penelitian ini, dikembangkan sebuah sistem pakar untuk mendeteksi penyakit tulang dan sendi. Sistem pakar dirancang dan dikembangkan dengan menggunakan metode runut maju (forward chaining). Kontribusi yang diberikan dari penelitian adalah aplikasi sistem pakar yang mampu menghasilkan output prediksi penyakit tulang dan sendi berdasarkan gejala-gejala yang dirasakan oleh pengguna.

\section{Metodologi Penelitian}

Metodologi yang digunakan dalam penelitian ini menggunakan pendekatan knowledge engineering yang berfokus kepada pengembangan sistem pakar. Dua bagian penting dalam pengembangan sistem pakar yaitu, basis pengetahuan dan proses reasoning atau inferensi [6].

Dalam menyusun basis pengetahuan, dilakukan dua kegiatan yaitu, akuisisi pengetahuan dan representasi pengetahuan. Akuisisi pengetahuan dilakukan dengan melakukan wawancara mendalam dengan pakar yang bertugas sebagai dokter spesialis bedah tulang dan sendi di Rumah Sakit Urip Sumoharjo, Bandar Lampung. Wawancara dilakukan beberapa kali untuk memastikan akurasi pengetahuan yang diakuisisi. Pengetahuan yang diperoleh dari pakar kemudian direpresentasikan ke dalam basis pengetahuan dalam bentuk tabel kode penyakit, gejala dan nama penyakit yang diderita. Kemudian setelah basis pengetahuan telah terbentuk, dilakukan identifikasi gejala-gejala utama untuk masing-masing penyakit. Setiap gejala kemudian diberikan nilai untuk memastikan akurasi pilihan jawaban. Selain itu, pemberian nilai juga ditujukan agar pengguna dapat mendefinisikan gejala lebih spesifik.

\subsection{Perancangan sistem}

Sistem yang dikembangkan terdiri dari dua sisi yaitu, sisi server dan client. Perancangan pada sisi server meliputi perancangan antarmuka, basis data dan mekanisme untuk pertukaran data client-server. Sementara itu pada sisi client, pengguna dapat mengakses aplikasi sistem pakar menggunakan peramban. Dengan menggunakan peramban, pengguna disajikan sejumlah daftar pertanyaan yang berkaitan dengan gejala yang dirasakan berikut dengan nilai yang dapat dipilih. Arsitektur sistem ditunjukkan pada gambar 1 .

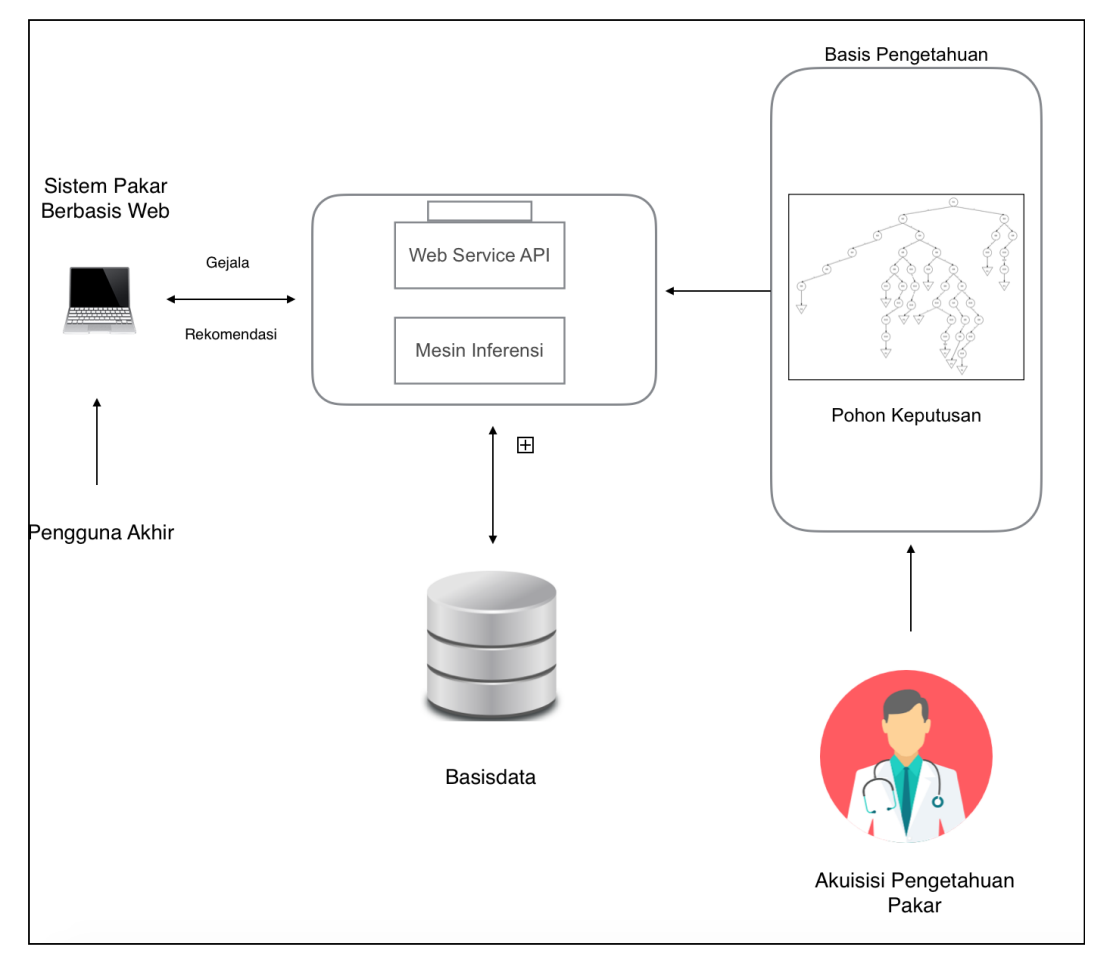




\subsection{Basis Pengetahuan}

Basis pengetahuan merupakan bagian penting dari sebuah aplikasi sistem pakar. Tahapan ini diawali oleh proses akuisisi pengetahuan pakar yang dilanjutkan dengan perancangan tabel dan pohon keputusan (decision tree) serta perancangan aturan produksi.

\subsection{Mesin Inferensi}

Mesin Inferensi menjadi bagian yang paling penting dalam membangun sistem pakar. Di dalam mesin inferensi, basis pengetahuan diolah sedemikian sehingga mencapai solusi atau kesimpulan. Adapun proses yang berlaku dalam mesin inferensi, yaitu proses manipulasi fakta, model dan kaidah yang tersimpan dalam basis pengetahuan. Beberapa jenis metode yang berjalan pada mesin inferensi antara lain : forward chaining (runut maju), backward chaining (runut mundur) dan gabungan dari kedua metode tersebut. Metode yang digunakan dalam penelitian ini adalah metode forward chaining (runut maju).

Metode runut maju atau forward chaining adalah mekanisme reasoning bottom-up yang diawali dari sekumpulan fakta dan berakhir pada goal (data-driven). Fakta adalah unit terkecil dari paradigma berbasis pengetahuan yang bilamana dipecah kembali tidak akan memiliki arti khusus. Sebagai contoh, bebek, yang merupakan kata benda. Jika bebek dipecah menjadi unit yang lebih kecil akan menjadi b-e-b-e-k yang tidak memiliki makna khusus [2]

Melalui pendekatan data-driven, proses reasoning dimulai dengan menggunakan informasi yang tersedia kemudian diakhiri dengan sebuah konklusi. Jika informasi pada anteseden pada aturan produksi terpenuhi maka aturan akan menghasilkan sebuah konklusi. Tetapi, jika konklusi yang dihasilkan bukan merupakan konklusi akhir maka akan terus dicari konklusi lainnya menggunakan aturan lainnya. Proses ini terus berlanjut hingga konklusi akhir dicapai [3].

Dalam penelitian ini hal yang pertama dilakukan oleh sistem adalah menelusuri gejala-gejala yang dirasakan oleh pasien kemudian diberikan kesimpulan berupa nama dan deskripsi penyakit yang diderita oleh pasien.

\section{Hasil dan analisis}

\subsection{Rekayasa pengetahuan}

Rekayasa pengetahuan dilakukan dengan melakukan wawancara mendalam dengan seorang pakar penyakit tulang dan sendi. Hasil wawancara dengan pakar diterjemahkan ke dalam bentuk representasi pengetahuan. Representasi pengetahuan terdiri dari dua elemen utama yaitu, fakta dan aturan Representasi pengetahuan bermanfaat untuk mempermudah pengkodean dalam perancangan sistem pakar. Representasi pengetahuan terdiri dari tabel keputusan, pohon keputusan dan aturan produksi. Langkah-langkah yang dilakukan dalam membuat representasi pengetahuan yaitu :

1. Pembuatan tabel keputusan untuk mendokumentasikan dan mendeskripsikan pengetahuan.

2. Pembuatan pohon keputusan untuk mencegah perulangan pertanyaan yang sama.

3. Pembuatan aturan produksi yang berasal dari konversi pohon keputusan. Tabel-tabel yang merepresentasikan pengetahuan disusun ke dalam tabel 1, 2 dan 3 :

\begin{tabular}{c|c} 
Kode & Penyakit \\
\hline P1 & Osteoporosis \\
P2 & Osteoarthritis \\
\hline P3 & Fraktur \\
P4 & Dislokasi \\
\hline & Tabel 1. Pengkodean Penyakit \\
\hline
\end{tabular}

Pemilihan keempat penyakit tersebut didasari oleh kecenderungan dari jumlah penyakit yang diderita oleh pasien berturut-turut yaitu, osteoporosis, osteoathritis, fraktur dan dislokasi [9]. Setelah empat penyakit dipilih kemudian dilakukan pengkodean untuk setiap penyakit.

Berdasarkan tabel penyakit, gejala dan nilai kemudian dibuat tabel keputusan antara gejala dan nilai yang akan disebut tabel keputusan aturan (ditunjukkan oleh tabel 4). Hal ini dilakukan untuk mendeskripsikan kemungkinan-kemungkinan gejala yang menyebabkan penyakit tertentu. Kemudian berdasarkan tabel keputusan antara gejala dan nilai dengan aturan, disusun tabel keputusan aturan dengan penyakit yang kemudian akan dihasilkan pohon keputusan (gambar 2). 


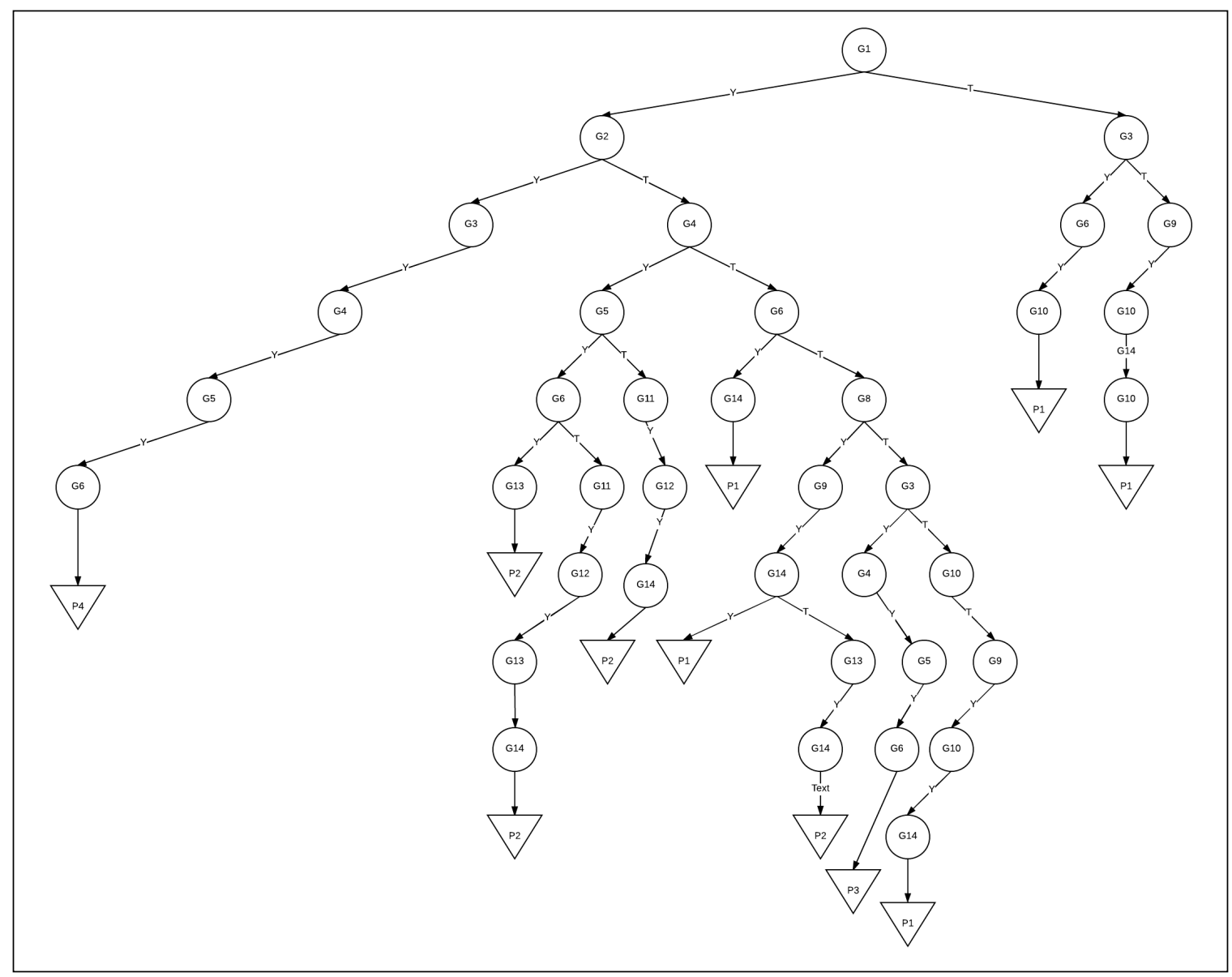

Gambar 2. Pohon Keputusan Gejala, Nilai dan Penyakit

Keterangan Gambar :

: Gejala

: Penyakit

Dari hasil pohon keputusan yang ditunjukkan pada gambar 2, setiap aturan akan ditelusuri oleh mesin inferensi. Penelusuran aturan didasari dari input berupa gejala dan nilai yang dimasukkan. Jika salah satu aturan telah terpenuhi maka aturan tersebut akan memiliki status fired dan aturan-aturan lain tidak akan ditelusuri. Tahapan reperesentasi pengetahuan berikutnya adalah mentransalasikan pohon keputusan di atas menjadi kaidah produksi. Aturan produksi disusun berdasarkan hasil analisis tabel dan pohon keputusan yang telah dibahas sebelumnya. Aturan produksi menggunakan aturan IF-THEN dimana klausa setelah IF disebut antecedent atau informasi masukan dan klausa setelah THEN disebut consequent atau konklusi [7].

Bentuk umum dari aturan produksi diagnosis penyakit tulang dan sendi didefinisikan sebagai berikut :

IF Nilai A AND Nilai B AND.... Nilai X THEN Rule Y 
Setelah didapatkan aturan yang fired, didapatkan penyakit yang memenuhi, dengan aturan produksi : IF Rule Y THEN Penyakit Z. Pada gambar 3, Y ditunjukan dengan sekumpulan gejala yang memiliki nilai, contohnya terjadi infeksi pada bagian tubuh, kemudian pengguna kesulitan bergerak dan seterusnya. Suatu penyakit sangat dimungkinkan memiliki beberapa gejala yang direpresentasikan ke dalam rule. Aturan produksi dilanjutkan dengan pencarian solusi dengan struktur sebagai berikut : IF Penyakit Z THEN Solusi C.

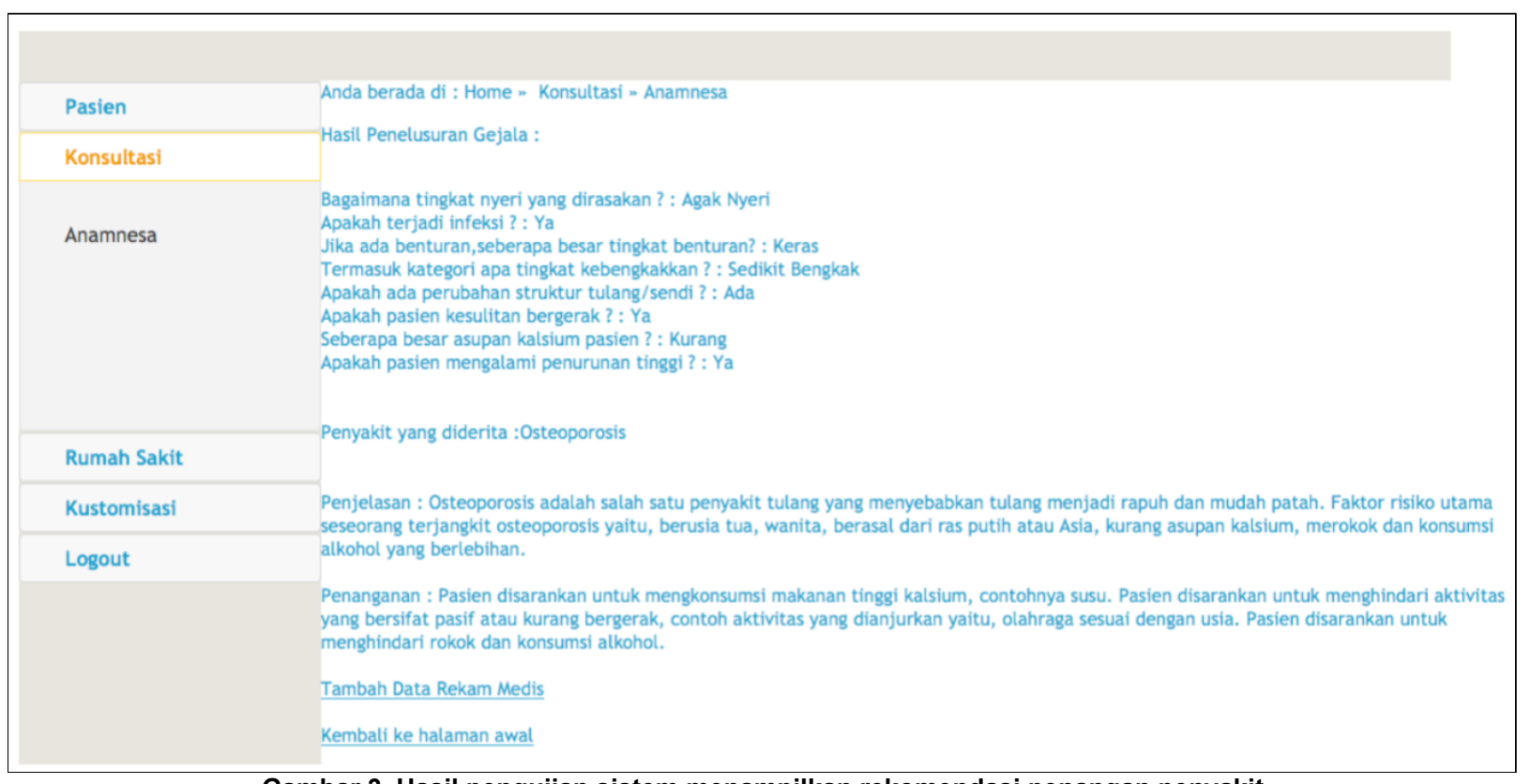

Gambar 3. Hasil pengujian sistem menampilkan rekomendasi penangan penyakit

Berdasarkan tabel keputusan yang disusun, kemudian disusun aturan produksi. Setiap aturan produksi diberikan kode tertentu. Adapun kode dan aturan produksi disajikan ke dalam tabel $\mathbf{5}$.

\begin{tabular}{|c|c|c|c|c|c|c|c|c|c|c|c|c|c|}
\hline \multirow{2}{*}{$\begin{array}{c}\text { Kode } \\
\text { Aturan } \\
\end{array}$} & \multicolumn{13}{|c|}{ Gejala } \\
\hline & G1 & G2 & G3 & G4 & G5 & G6 & G8 & G9 & G10 & G11 & G12 & G13 & G14 \\
\hline R1 & $\mathrm{N} 2$ & & & & & N14 & & & & & & & N33 \\
\hline $\mathbf{R 2}$ & N2 & & & & & & N16 & N18 & & & & & N33 \\
\hline R3 & & N6 & & & & N14 & & & $\mathrm{N} 21$ & & & & \\
\hline R4 & N1 & & & & & & N16 & N18 & & & & & \\
\hline R5 & & & & & & & & N18 & $\mathrm{N} 21$ & & & & N33 \\
\hline R6 & $\mathrm{N} 2$ & & & N10 & N12 & N14 & & & & & & N29 & \\
\hline R7 & $\mathrm{N} 2$ & & & & & N14 & & & & & & N29 & N33 \\
\hline R8 & $\mathrm{N} 2$ & & & N11 & N12 & & & & & $\mathrm{N} 23$ & $\mathrm{~N} 25$ & & N33 \\
\hline R9 & N1 & & & N10 & N12 & & & & & $\mathrm{N} 23$ & N25 & $\mathrm{N} 29$ & N33 \\
\hline R10 & N2 & & & N11 & & & & & & $\mathrm{N} 23$ & $\mathrm{~N} 25$ & & $\mathrm{~N} 33$ \\
\hline R11 & $\mathrm{N} 2$ & N5 & N6 & N11 & N12 & N14 & & & & & & & \\
\hline R12 & $\mathrm{N} 2$ & & N7 & N9 & \begin{tabular}{|l} 
N12 \\
\end{tabular} & N14 & & & & & & & \\
\hline R13 & N1 & N5 & N7 & N10 & N12 & N14 & & & & & & & \\
\hline R14 & N1 & $\mathrm{N} 4$ & N7 & N10 & N12 & N14 & & & & & & & \\
\hline R15 & $\mathrm{N} 2$ & N5 & N6 & N11 & N12 & N14 & & & & & & & \\
\hline R16 & $\mathrm{N} 2$ & $\mathrm{~N} 4$ & N6 & N11 & N12 & N14 & & & & & & & \\
\hline
\end{tabular}

Tabel 4. Tabel Keputusan Aturan Dengan Gejala dan Nilai

Untuk menghasilkan kesimpulan penyakit yang diderita, sistem meminta masukkan dari pengguna yang berbentuk pertanyaan dan nilai. Masukkan dari pengguna kemudian dianalisis oleh sistem dengan cara runut maju, ketika kondisi tertentu sudah dipenuhi, maka sistem akan menampilkan kesimpulan / konklusi. Gambar 3 menunjukkan hasil pengujian sistem yang menampilkan kesimpulan penyakit yang diderita oleh pasien 
Kesimpulan yang diambil oleh sistem berdasarkan data nilai dari gejala yang dimasukkan oleh pengguna adalah osteoporosis. Osteoporosis merupakan salah satu penyakit tulang yang menyebabkan tulang menjadi rapuh dan mudah patah. Sistem juga menampilkan penanganan yang disarankan bagi pasien penderita osteoporosis. Selain ditampilkan hasil penelusuran, identifikasi penyakit dan penanganan pengguna juga bisa melakukan input data rekam medis.

Pengujian terhadap hasil dilakukan dengan melakukan uji skenario penelusuran penyakit berdasarkan gejala yang dimasukkan. Uji skenario dilakukan dengan melakukan $\mathrm{N}$ kali percobaan. Percobaan dilakukan oleh pakar di mana pakar disediakan lembar evaluasi pengujian akurasi sistem pakar. Tingkat akurasi diperoleh dengan cara melakukan percobaan yang dilakukan oleh pakar. Tujuan dari pengujian aplikasi sistem pakar adalah untuk menguji efektifitas dan akurasi sistem yang dikembangkan. Efektifitas didefinisikan jumlah pertanyaan yang diajukan oleh sistem sebelum memberikan luaran berupa penyakit yang diderita. Hasil akhir pengujian sistem diperoleh dengan cara membandingkan hasil prediksi penyakit yang diderita oleh aplikasi sistem pakar dengan diagnosa atau kesimpulan akhir yang dilakukan oleh Dokter Spesialis Bedah Tulang dan Sendi. Kesimpulan akhir dilakukan dengan melakukan anamnesa, pemeriksaan fisik dan pemeriksaan penunjang lainnya oleh pakar.
No
Pertanyaan
$1 \quad$ Bagaimana tingkat nyeri yang dirasakan?
Jawaban
Sangat Nyeri (11) (55\%), Agak Nyeri (9) $(45 \%)$
$2 \quad$ Apakah terjadi infeksi ?
3 Jika ada benturan,seberapa besar tingkat benturan?
Ya (5) (25\%), Tidak (15) $(75 \%)$
Keras (5) (25\%), Tidak terjadi (9) (45\%), Lemah (6) (30\%)
4 Termasuk kategori apa tingkat kebengkakkan?
Sangat bengkak (7) (35\%), Tidak bengkak (5) $(25 \%)$, Agak bengkak (6) (30\%), Sedikit bengkak (2) (10\%)
$5 \quad$ Apakah ada perubahan struktur tulang/sendi ?
Ada (14) (70\%), Tidak (6) (30\%)
6 Apakah pasien kesulitan bergerak? Ya (16) (80\%), Tidak (4) (20\%)
Tabel 6. Rekapitulasi hasil uji skenario sistem pakar

Pada tabel 6 disajikan enam pertanyaan pertama yang diajukan oleh sistem. Kolom jawaban merupakan rekapitulasi jawaban yang dimasukkan oleh pengguna pada saat melakukan uji sistem. Presentase yang mengikuti nilai pada kolom jawaban merupakan presentasi jumlah nilai jawaban relatif terhadap $\mathrm{N}$ kali percobaan uji coba.

\section{Kesimpulan}

Berdasarkan hasil perancangan, implementasi dan pengujian terhadap sistem, diperoleh kesimpulan bahwa perancangan aplikasi sistem pakar untuk diagnosis penyakit tulang dan sendi berbasis web telah berhasil diimplementasikan sesuai rancangan. Berdasarkan hasil pengujian, aplikasi sistem pakar yang dirancang dengan metode forward chaining (runut maju) mampu mengidentifikasi penyakit tulang dan sendi yang meliputi penyakit osteoporosis, osteoarthritis, dislokasi dan fraktur sesuai dengan pengetahuan pakar. Pengujian dilakukan dengan metode black-box. Metode tersebut bertujuan untuk memastikan sistem mampu menghasilkan output yang sesuai [10]. Dari hasil uji black-box, diketahui bahwa 45\% percobaan pada sistem mampu menyimpulkan penyakit yang diderita oleh pasien berdasarkan enam gejala utama penyakit tanpa harus mengajukan pertanyaan lanjutan kepada pasien. Enam gejala tersebut merupakan gejala umum dari penyakit yang diderita oleh pasien. Sistem ini baru bisa memprediksi empat penyakit utama dari penyakit tulang dan sendi berdasarkan gejala yang dipresentasikan menggunakan teks. Di pengembangan berikutnya, perlu dilakukan pengembangan berupa penambahan fitur gambar rontgen dengan deteksi citra untuk memperoleh hasil yang lebih akurat. 


\section{Daftar pustaka}

[1] Sharma, T., Tiwari, N., Kelkar, D., " Study of Difference Between Forward and Backward Reasoning", International Journal of Emerging Technology and Advanced Engineering , vol. 2, issue 10, 2012

[2] Giarratano, J., Riley, G.,"Expert System Principles and Programming”, Third Edition. Boston: PWS Publishing Company, 2005

[3] Turban, E., Aronson, J., Liang, TP., "Decision Support Systems and Intelligent Systems (Sistem Pendukung Keputusan dan Sistem Cerdas)", ANDI, Yogyakarta, 2005

[4] Putra, A. (private communication), 2017

[5] Kemenkes, "Menkes Soroti Masalah Maldistribusi Dokter Spesialis Indonesia", Agustus 2017, http:// www.depkes.go.id/article/print/17022400008/menkes-soroti-masalah-maldistribusi-dokter-spesialisindonesia.html

[6] Studer, R., Benjamins, V,R., Fensel, D., "Data and Knowledge Engineering”, Elsevier Science, 1998

[7] Sulistyohati, A., Hidayat, T., Aplikasi Sistem Pakar Diagnosa Penyakit Ginjal Dengan Metode DempsterShafer, Prosiding, Seminar Nasional Aplikasi Teknologi Informasi Universitas Islam Indonesia Yogyakarta, 2008

[8] Fadhilah, A, N., Destiani, D., Dhamiri, D, J., Perancangan Aplikasi Sistem Pakar Penyakit Kulit Pada Anak Dengan Metode Expert System Development Life Cycle, Jurnal Algoritma Vol 9, Sekolah Tinggi Teknologi Garut, 2012

[9] Tarigan, M., https://m.tempo.co/read/news/2012/02/20/173385164/jumlah-dokter-orthopedhi-indonesiakalah-dengan-thailand, 2012

[10] Shilvia, N, M., Rahayu, S., Pengembangan Sistem Pakar Diagnosa Awal Penyakit Dalam Internis Berbasis Android, Jurnal Algoritma Vol 13 No.1 Hal 356-366, Sekolah Tinggi Teknologi Garut, 2016 


\section{Lampiran}

\begin{tabular}{|c|c|c|}
\hline $\begin{array}{l}\text { Kode } \\
\text { Nilai }\end{array}$ & Kode Gejala & Nilai \\
\hline $\mathrm{N} 1$ & G1 & Agak Nyeri \\
\hline N2 & G1 & Sangat Nyeri \\
\hline N3 & G1 & Tidak Terasa Nyeri \\
\hline N4 & $\mathrm{G} 2$ & Ya \\
\hline N5 & G2 & Tidak \\
\hline N6 & G3 & Keras \\
\hline N7 & G3 & Lemah \\
\hline N8 & G3 & Tidak Terjadi \\
\hline N9 & G4 & Sedikit Bengkak \\
\hline N10 & G4 & Agak Bengkak \\
\hline N11 & G4 & Sangat Bengkak \\
\hline N12 & G5 & Ada \\
\hline N13 & G5 & Tidak \\
\hline N14 & G6 & Ya \\
\hline N15 & G6 & Tidak \\
\hline N16 & G8 & Kurang \\
\hline N17 & G8 & Normal \\
\hline N18 & G9 & Ya \\
\hline N19 & G9 & Tidak \\
\hline N20 & G10 & Rendah \\
\hline N21 & G10 & Sedang \\
\hline N22 & G10 & Tidak Mengkonsumsi \\
\hline N23 & G11 & $\mathrm{Ya}$ \\
\hline N24 & G11 & Tidak \\
\hline N25 & $\mathrm{G} 12$ & Pagi \\
\hline N26 & G12 & Siang \\
\hline N27 & G12 & Malam \\
\hline N28 & G12 & Setiap Saat \\
\hline N29 & G13 & $\mathrm{Ya}$ \\
\hline N30 & G13 & Tidak \\
\hline N31 & G14 & Anak-anak \\
\hline N32 & G14 & Dewasa \\
\hline N33 & G14 & Tua \\
\hline N34 & G4 & Tidak Bengkak \\
\hline
\end{tabular}




\begin{tabular}{|c|c|c|}
\hline $\begin{array}{l}\text { Kode } \\
\text { Solusi }\end{array}$ & Nama Penyakit & Solusi \\
\hline S1 & Osteoporosis & $\begin{array}{l}\text { Pasien disarankan untuk mengkonsumsi makanan tinggi kalsium, } \\
\text { contohnya susu. Pasien disarankan untuk menghindari aktivitas yang } \\
\text { bersifat pasif atau kurang bergerak, contoh aktivitas yang dianjurkan } \\
\text { yaitu, olahraga sesuai dengan usia. Pasien disarankan untuk } \\
\text { menghindari rokok dan konsumsi alkohol. }\end{array}$ \\
\hline S2 & Osteoarthritis & $\begin{array}{l}\text { Pasien disarankan untuk mengurangi berat badan serta menghindari } \\
\text { aktivitas naik-turun tangga atau berjalan terlalu jauh. Pasien juga } \\
\text { disarankan untuk menghindari udara yang terlalu dingin. } \\
\text { Penanganan bisa dilanjutkan dengan fisioterapi untuk membantu } \\
\text { agar sendi tidak kaku. }\end{array}$ \\
\hline S3 & Dislokasi & $\begin{array}{l}\text { Harus secepatnya melakukan reposisi oleh dokter. Pasien } \\
\text { disarankan untuk menghindari aktivitas-aktivitas yang bisa } \\
\text { menimbulkan trauma pada daerah yang terjadi dislokasi. }\end{array}$ \\
\hline S4 & Fraktur & $\begin{array}{l}\text { Harus secepatnya dilakukan tindakan medis. Pasien disarankan } \\
\text { untuk tidak melakukan aktivitas yang menggunakan daerah yang } \\
\text { terjadi fraktur sebelum terjadi penyembuhan (dibuktikan dengan } \\
\text { rontgen). Pasien juga disarankan untuk mengkonsumsi makanan } \\
\text { yang tinggi kalori dan tinggi protein, contohnya susu dan ikan. }\end{array}$ \\
\hline
\end{tabular}

Tabel 3. Pengkodean penyakit dan solusi 